\title{
DIRASAH
}

Volume 3, Number 2, Agustus 2020

p-ISSN: 2615-0212 | e-ISSN: 2621-2838

https://ejournal.iaifa.ac.id/index.php/dirasah

\begin{tabular}{|c|c|c|}
\hline Accepted: & Revised: & Published: \\
April 2020 & Mei 2020 & Agustus 2020 \\
\hline
\end{tabular}

\section{Peran Kepala Sekolah dalam Pembetukan Karakter Siswa melalui Business Day School di SDITAl-Huda Sangkapura}

\author{
Defi Dachlian Nurdiana
}

STAI Hasan Jufri Bawean, Indonesia

e-mail:defi.dachlian@gmail.com

\begin{abstract}
The headmaster is a functional force that is given the authority and trust of certain educational institutions to plan, regulate, control, and evaluate all policies in the institution in order to achieve the vision and mission. The focus of this research is to examine the role of the headmaster in the formation of student mone through business day school in Sdit Al-Huda Sangkapura. This research is a qualitative case study with observational data retrieval, interviews, as well as documentation. The results of the study explained that: (1) The headmaster always evaluates the activities in SDIT Al-Huda by meeting every weekend and teacher Council considering continuation and improving the quality of Business day school program to become the flagship program in SDIT Al-Huda. (2) with the Business day School Program students learn entrepreneurship, self-reliance, arithmetic, confident and communicative.
\end{abstract} Keywords: role of school principal, business day school, character. 


\begin{abstract}
Abstaksi
Kepala sekolah merupakan tenaga fungsional yang diberikan wewenang dan kepercayaan dari lembaga pendidikan tertentu untuk merencanakan, mengatur, mengontrol, dan mengevaluasi segala kebijakan-kebijakan yang ada di lembaga pendidikan tersebut demi tercapainya visi dan misi. Fokus penelitian ini adalah mengkaji peran kepala sekolah dalam pembentukan karakte siswa melalui business day school di SDIT Al-Huda Sangkapura. Penelitian ini adalah kualitatif studi kasus dengan pengambilan data secara observasi, wawancara, serta dokumentasi. Hasil penelitian menjelaskan bahwa: (1) kepala sekolah senantiasa mengevaluasi aktifitas yang ada di SDIT Al-Huda dengan cara mengadakan rapat di setiap akhir pekan beserta dewan guru mempertimbangkan kelanjutan dan meningkatkan kualitas program business day school menjadi program unggulan di SDIT Al-Huda. (2) dengan program business day school siswa belajar kewirausahaan, kemandirian, aritmatika, percaya diri dan komunikatif.
\end{abstract}

Kata Kunci : peran kepala sekolah, business day school, karakter.

\title{
Pendahuluan
}

Sekolah atau madrasah merupakan sebuah organisasi pembelajaran merupakan kumpulan dari individu-individu pembelajar yang ada di dalamnya. Sebuah madrasah atau sekolah dikatakan sebagai organisasi pembelajaran jika memiliki ciri-ciri (1) sekolah memberikan kesempatan dan mendorong setiap individu yang ada di dalamnya untuk terus belajar dan memperluas kapasitas dirinya, serta (2) sekolah tersebut merupakan organisasi yang siap menghadapi perubahan dengan mengelola perubahan itu sendiri (managing change). Sehingga akan terlihat bahwa proses pembelajaran yang ada di sekolah tersebut bukanlah suatu pembelajaran yang terjadi secara alami dan juga bukan sebuah pembelajaran secara kebetulan, namun sebuah pembelajaran yang telah di konsep sesuai dengan manajemen pengelolaan lembaga pendidikan. ${ }^{1}$

Penguasaan pribadi (personal mastery) merupakan suatu budaya dan norma organisasi yang diterapkan sebagai cara bagi semua individu dalam organisasi untuk bertindak dan melihat dirinya. Diharapkan personal mastery ini dimiliki oleh orang-orang yang mengelola lembaga pendidikan, karena di lembaga pendidikan akan dituntut pada semua jenis mata pelajaran untuk mampu menginternalisasikan kecakapan hidup (life skill). Hal tersebut tidak

\footnotetext{
${ }^{1}$ Muhaimin, dkk., "Manajemen Pendidikan: Aplikasi dalam Peyusunan Rencana Pengembangan Sekolah /Madrasah”, ( Kencana: Jakarta, 2011), 90.
}

Dirasah, Vol. 3, No.2, Agustus 2020 
mudah untuk di wujudkan jika para pengelola pendidikan dan guru tidak memiliki kemampuan untuk mengenal dirinya sendiri dalam menerapkan nilainilai ini kepada siswa. ${ }^{2}$

Salah satu konsep yang dapat dikembangkan oleh lembaga pendidikan dalam menciptakan sebuah organisasi sekolah yang mampu mengembangkan potensi siswa secara luas dengan terus belajar melalui pendidikan karakter yang di tanamkan kepada siswa selama proses pembelajaran di lembaga atau organisasi pendidikan tersebut. Dengan pendidikan karakter yang tepat dapat membentuk jiwa siswa menjadi sopan, santun, mandiri, percaya diri, kreatif, dan inovatif. Sehingga siswa akan mampu menghadapi dinamika perubahan di era globalisasi. Hal tersebutlah yang membuat para pengelola lembaga pendidikan terus berinovasi dalam menciptakan lulusan yang mampu bertahan dalam perubahan revolusi industry 4.0. Untuk mempersiapkan luluasan yang mampu menghadapi tantangan revolusi industry 4.0 dibutuhkan personal masterydi lembaga pendidikan dengan melatih pengelola lembaga, guru dengan mengutamakan pada aspek pengembangan kejiwaan. Salah satu metode yang dapat dikembangkan dalam pembelajaran pendidikan karakter bagi siswa yaitu dengan penanaman jiwa kewirausahaan sejak dini. Kegiatan kewirausahaan ini akan mampu menciptakan karakte siswa yang mandiri, pecaya diri, kreatif, dan inovatif. Dengan pendekatan kewirausahaan yang ada di sekolah akan ada transformasi budaya kewirausahaan dari guru ke siswa.

Dalam prosesnya pendekatan kewirausahaan akan melalui proses yang panjang, dikarenakan belum adanya pengalaman sama sekali yang di miliki oleh siswa, baik itu dari lingkungan tempat tinggalnya maupun di lingkungan sekolah. Oleh karena itu bagi para lembaga pendidikan dan pelatihan yang mengembangkan aspek kewirausahaan pasti memiliki tujuan agar siswa mampu menguasai kegiatan ekonomi dengan baik yang meliputi produksi, distribusi dan konsumsi. Kebanyakan lembaga pendidikan berfokus pada kemampuan siswa dalam pelajaran secara akademik saja dan minim lembaga pendidikan yang menanamkan jiwa kewirausahaan kepada siswanya. Sehingga lulusan yang dihasilkan kebanyakan sebagai tenaga siap pakai dan bukan pencipta lapangan pekerjaan. Melalui program kewirausahaan yang telah dibiasakan di sekolah pada saat proses belajar secara tidak langsung dapat membentuk karakter siswa-siswanya sebagai seorang wirausahawan. Dimulai dari sekolah

${ }^{2}$ Ibid.91

Dirasah, Vol.3, No. 2, Agustus 2020 
dasar sebagai lembaga pendidikan yang mempunyai pean penting dalam pembentukan karakter, meskipun dalam kurikulumnya tidak mewajibkan mempelajari tentang kewirausahaan. Program kegiatan wirausaha di sekolah merupakan inovasi dan kreatifitas dari lembaga pendidikan terhadap fenomena yang social yang ada, sebagai salah satu upaya mencegah dan mengurangi angka pengangguran terdidik. Sehingga program kegiatan kewirausahaan dilaksanakan di beberapa lembaga pendidikan yang benar-benar siap secara sarana dan prasarana seta kebijakan intenal dari pengelola lembaga pendidikan. Oleh karena itu perlunya dukungan dari beberapa pihak tentunya dari pemerintah untuk menumbuhkan jiwa kewirausahaan dalam dunia pendidikan mendapatkan pehatian yang lebih.

Sebagaimana penjelasan diatas lembaga pendidikan yang baik adalah lembaga pendidikan yang terus belajar dan memperluas kapasitas dirinya serta dapat menghadapi perubahan dengan mengelola perubahan itu sendiri. Salah satu lembaga pendidikan yang telah menerapkan keterampilan kewirausahaan kepada siswanya yakni SDIT AL-HUDA Sangkapura Bawean Gresik melalui program Business Day School.

\section{Pembahasan}

\section{Kepemimpinan Sekolah atau Madrasah}

Kepala sekolah dapat di artikan sebagai ketua atau pemimpin dalam suatu organisasi atau lembaga sekolah. Secara sederhana kepala sekolah diartika sebagai seorang tenaga fungsional yang diberi tugas untuk memimpin suatu sekolah yang diberi wewenang dan tugas untuk memimpin suatu lembaga pendidikan dimana diselenggaraka proses belajar mengajar atau tempat dimana terjadinya interaksi antara guru sebagai penyalur ilmu dengan peserta didik sebagai penerima ilmu. ${ }^{3}$

Kepala sekolah merupakan seorang pendidik (guru) atau seorang yang dipercaya oleh penyelenggara sekolah(dinas pendidikan mengandalikan kepala sekolah) untuk mengatur dan mengurus apa saja yang berkaitan dengan lembaga tersebut. ${ }^{4}$ Jadi kepala sekolah merupaka tenaga fungsional yang diberikan wewenang dan kepercayaan dari lembaga pendidikan tertentu untuk merencanakan, mengatur, mengontrol, dan mengevaluasi segala kebijakan-

\footnotetext{
${ }^{3}$ Euis karwati,kinerja dan profesionalisme kepala sekolah,(Bandung : Alfabeta, 2013), 37.

${ }^{4}$ Alben ambarita,kepemimpinan kepala sekolah,(Yogyakarta : Graha ilmu, 2015), 59.
}

Dirasah, Vol. 3, No.2, Agustus 2020 
kebijakan yang ada di lembaga pendidikan tersebut demi tercapainya visi dan misi pendidikan nasional.

Sehingga kepemimpinan meupakan salah satu factor penting dan beperan dalam organisasi ataupun lembaga pendidikan. Factor pemimpin memegang peranan penting dalam pengembangan lembaga pendidikan, seorang pemimpin harus mempunyai karakter yang kuat dalam melaksanakan tugas dan tanggungjawabnya. Sebagaimana dikemukakan oleh Covey (2005) bahwa 90 pesen kegagalan kepemimpinan adalah kegagalan pada karakter. Dalam teori sifat menyatakan bahwa para pemimpin dianugrahi sifat-sifat yang lebih unggul, sehingga menyebabkan pemimpin tesebut bebeda dengan orang lain. Hal tesebut berbanding tebalik dengan pendapat yang dikemukakan oleh Hersy dan Blachard yang menyaakan bahwa kepemimpinan adalah hasil dari tuntutantuntutan situasional, dimana factor situasional inilah yang akan menentukan siapa yang akan muncul sebagai seorang pemimpin daripada warisan genetic atau sifat yang dimiliki seseorang. ${ }^{5}$

Agar seorang kepala sekolah atau madrasah mampu menggeakkan anggota dalam mengembangkan lembaga pendidikannya dibutuhkan unsurunsur yang dimiliki seorang kepala sekolah atau madrasah dalam mengembangkan lembaga pendidikannya, diantaranya (1) memiliki visi, seorang pemimpin harus memiliki visi yang baik, pemikiran yang tebuka agar ia mampu menerima bebagai hal baru yang mungkin saja selama ini bertentangan dengan apa yang telah diyakininya, sehingga pengalaman tesebut akan mampu memperkaya perspektif pandangan seorang kepala sekolah tehadap sesuatu. (2) kebeanian, seorang kepala sekolah yang mencintai pekejaannya akan memiliki keberanian yang tinggi berarti ia akan megerjakan tugas dan tanggungjawabnya dengan sepenuh hati. Dengan keberanian tesebut pemimpin akan melakukan terobosan-terobosan baru yang penuh resiko, sehingga akan mampu memotivasi anggota dan membeikan teladan yang baik. (3) realita, seorang kepala sekolah harus mampu membedakan mana opini dan mana fakta. Ia harus mampu hidup dalam kondisi realitas lembaga yang dikelolanya, jika kondisi sekolah atau madrasahnya masih belum memiliki sumbe daya yang cukup maka kepala sekolah harus mampu memaksimalkan fasilitas yang ada dengan terus berupaya memenuhi sumber daya tesebut. (4) etika, yang harus dimiliki seorang kepala sekolah atau madrasah tidak sekedar

\footnotetext{
${ }^{5}$ Muhaimin, dkk., “Manajemen Pendidikan: Aplikasi dalam Peyusunan Rencana Pengembangan Sekolah /Madrasah", ( Kencana: Jakarta, 2011), 29.
} 
mampu memimpin secara legalitas di lembaga pendidikan saja, namun juga memiliki kepedulian yang tinggi tehadap lingkungan disekitarnya. Bekeja dengan belandaskan nilai-nilai kemanusiaan yang luhur, menanamkannya dan menghukumnya bagi mereka yang melanggar nilai-nilai. Penanaman nilai-nilai di sekolah akan membuat lembaga pendidikan lebih produktif dalam proses pengembangan. ${ }^{6}$

\section{Business Day School}

Business day school merupakan kegiatan kewirausahaan yang dilakukan di sekolah yang atur sedemikian rupa sehingga menarik dan menyenangkan bagi siswa yang akan belajar untuk menumbuhkan kemampuan entrepreneurship sejak dini. ${ }^{7}$ Business dayschool merupakan kegiatan pembelajaran tentang enterpreneur, dimana siswa diajarkan tentang pemahaman kegiatan ekonomi dimulai dari kegiatan produksi hingga pemasaran atau distribusi. Dalam kegiatan business day school produk yang dimiliki oleh siswa akan dipasarkan kepada teman, guru, atau wali siswa yang sengaja dating saat mengantar sekolah. Kegiatan business day school akan melibatkan semua komponen pengelola lembaga pendidikan. Umumnya yang menjadi pembeli adalah siswa, guru, dan orang tua yang mengantar dan menjemput siswa, masyarakat disekitar lingkungan sekolah yang berkunjung ke lembaga pendidikan. Setiap kelas umumnya memiliki lapak dagangannya sendiri. Kadang-kadang setiap kelas menyajikan tema dan barang dagangannya yang khas, pelaksanaan business day school ini suasana dibuat jadi riang gembira.

Dengan mengembangkan jiwa kewirausahaan pada siswa akan mampu membangun rasa percaya diri dan sikap madiri dalam diri siswa, melalui pembiasaan dengan kegiatan wirausaha siswa akan belajar bagaimana cara memasarkan sebuah produk, mengatasi kegagalan saat produk mereka tidak diminati oleh konsumen, belajar bagaimana berinovasi agar berbeda dengan yang lain, belajar bangkit dari kegagalan, belajar memotivasi diri sendiri, serta belajarcepat tentang menghitung atau mengelola uang dengan baik.

Tujuan utamanaya kegiatan kewirausahaan adalah mengasah kecerdasan emosional siswa. Menurut Goleman, kecerdasan emosional adalah kecakapan

\footnotetext{
${ }^{6}$ Ibid. 32

${ }^{7}$ Ela fitria rahma, "Menumbuhkan Kemampuan Enterpreneurship Anak Melalui Kegiatan Market Day di Kelompok B TK putri Serang Sumber Surakarta" (Skripsi Universitas Muhammadiyah, Surakarta, 2016), 6.
}

Dirasah, Vol. 3, No.2, Agustus 2020 
yang meliputi kemampuan untuk mengendalikan diri sendiri, memiliki daya tahan ketika menghadapi rintangan, mengendalikan gejolak, tidak cepat merasa puas, mengatur suasana hati, dan mengelola kecemasan agar tidak mengganggu kemampuan berfikir dan kemampuan berempati, serta berharap kecerdasan emosional adalah mudah mengenali emosi orang lain, serta penuh perhatian. ${ }^{8}$

Adapun manfaat belajar kewirausahaan diantaranya (1) Mengenal dan memahami seluk beluk dunia usaha, (2) Mengasah talenta siswa yang mempunyai semangat berwirausaha, (3) Mempunyai bekal ilmu, selain pendidikan formal untuk diaplikasikan sewaktu-waktu dan (4) Mengetahui alternatif cara mencari uang selain bekerja sebagai karyawan, serta (5) Mempunyai arah untuk menjadi pengusaha yang sukses. ${ }^{9}$

\section{Peran Kepala Sekolah Dalam Business Day School Di Sdit Al Huda Sangkapura}

Business dayschool merupakan upaya-upaya kreatif dan Inovatif untuk menumbuhkan jiwa kewirausahaan atau enterpreniurship. Sesuai dengan tujuannya, untuk menumbuhkan jiwa kewirausahaan maka business dayschool dilakukan dengan cara menerapkan hal-hal yang kreatif dan inovatif. Sesuai dengan informasi dari kepala sekolah SDIT Al-Huda sebagai berikut"Tujuan kegiatan business day schoolini untuk mengembangkan jiwa interpreunership dan penguat karakterpeserta didik sejak dini". ${ }^{10}$ Untuk mencapai tujuan tersebut maka bussiness day school diterapkan setiap bulan pada minggu pertama, tepatnya di hari Jumat.

Manfaat kegiatan bussiness day school ini diterapkan di SDIT Al-Huda dengan harapan dapat menumbuhkan beberapa kemampuan dan keterampilan berkomunikasi pada setiap siswa. Dengan tumbuhnya keterampilan berkomunikasi dan berinteraksi maka akan bisa menumbuhkan kreatifitas dan meningkatkan rasa percaya diri. Sepeti yang disampaikan Kepala Sekolah SDIT Al-Huda sebagai berikut:

"Adapun manfaat kegiatan bussiness day schoolini dapat menumbuhkan beberapa kemampuan dan keterampilan seperti rasa percaya diri, dengan adanya kegiatan seperti ini tingkat

\footnotetext{
${ }^{8}$ Daniel Geloman, penerjemah: T. Hermaya, kecerdasan Emosional, (Jakarta : PT. Gramedia Pustaka Utama, 2009), 13.

${ }^{9}$ Wulan Ayodya,SiswaJuga Bisa Jadi Pengusaha: Tips dan Trik Belajar Berwirausaha Bagi Siswa,(Jakarta : Esensi, 2011), 5.

${ }^{10}$ Elia Puspa, Kepalasekolah SDIT Al-Huda.
} 
kepercayaan diri siswa dalam melakukan interaksi baik kepada teman sebaya, pembeli, dan guru, maka peserta didik lebih terlatih mentalnya sehingga kepercayaan dirinya juga terlatih. Keterampilan lain yang bisa di ambil manfaatnya adalah peserta didik bisa belajar matematika secara cepat, seperti dalam hal menghitung uang kembalian dari barang yang dijual. Dalam hal ini, peserta didik diasah dalam keterampilan aritmatis. ${ }^{11}$

Jadi manfaat dari kegiatan bussiness day school bisa menumbuhkan rasa percaya diri, melatih kemampuan berhitung serta melatih jiwa kepemimpinan, selain itu bussiness day schooljuga dapat membentuk mental peserta didik yang memiliki motivasi yang kuat, kerja keras, dan pantang menyerah.

Waktu rutin pelaksanaan kegiatan bussiness day schooldi SDIT Al-Huda ini adalah setiap bulan pada minggu pertama, tepatnya di hari Jumat. Pelaksanaan kegiatan bussiness day schoolsendiri dimulai dari jam 06.00-09.00 WIB dan pelaksanaan kegiatan bussiness day schoolini bertempat di halaman sekolah SDIT Al-Huda. Sesuai dengan informasi dari kepala sekolah SDIT AlHuda sebagai berikut:

Kegiatan business day schooldi SDIT Al-Hudaini berakhir pada jam 09.00 WIB, kegiatan ini dimulai dari jam 06.00 dan berakhir pada jam 09.00 WIB. Pelaksanan kegiatan business day school ini bertempat di halaman sekolah, jadi di halaman sekolah ini kalau sudah hari jum'at itu berisi stand-stand siswa dari kelas 1 hingga kelas 6 SDIT Al-Huda yang sedang melakukan kegiatan business day school. ${ }^{12}$

Setiap kelompok (stand) memiliki satu guru pendamping yang akan mengarahkan proses pelaksanaan business day school. Sesuai dengan informasi dari Waka Kurikulum SDIT Al-Huda sebagai berikut:

Guru merencanakan stand, karena sekolah SDIT Al-Huda disini setiap kelasnya punya lapak atau stand. Stand dari bambu yang di paku, besarnya semeja kakinya 4 kemudian ada tiangnya keatas yang ini ada papannya untuk nama standnya. Stand kelas berapa dan ada benner, setiap kelas punya benner, model papan nama terserah kreatifitas guru dan siswa, misalnya foto siswa di pasang kemudian di print di kasih gritfo, gritsix, bagian bawah stand kita hias dengan cat. ${ }^{13}$

\footnotetext{
${ }^{11}$ Elia Puspa, Kepala sekolah SDIT Al-Huda, wawancara, Bawean, 5 April 2019.

${ }^{12}$ Elia Puspa, Kepala sekolah SDIT Al-Huda, wawancara, Bawean, 5 April 2019.

${ }^{13}$ Evi Cornelia Sinsu, Waka kurikulum SDIT Al-Huda, wawancara, Bawean 23 April 2019.
}

Dirasah, Vol. 3, No.2, Agustus 2020 
Guru pendamping juga yang akan membagi tugas kepada setiap peserta didik, misalnya tugas di bagian kasir, bendahara, kebersihan dan lainlain. Sesuai dengan informasi dari Waka Kurikulum SDIT Al-Huda sebagai berikut:

Guru menekankan peserta didik, Guru mengorganizing siapa saja ketuanya . ketua acara business day bulan ini misalnya tgl 5 April 2019, kemudian bendaharanya siapa, guru tempatkan bendahara 2 orang, siapa kebersihan, pemasaran siapa. Sekalipun masih SD guru di SDIT Al-Huda sudah masukkan ilmu-ilmu manajemen. Guru bagi tugas organizing dengan lengkap. ${ }^{14}$

Tiga jam pelaksanaan kegiatan business day schoolini dilakukan dengan full tanpa adanya istirahat. Setelah kegiatan selesai, siswa melakukan kegiatan bersih-bersih yang di dampingi kembali oleh guru. Kemudian, siswa kembali masuk ke kelas masing-masing untuk menghitung hasil perolehan penjualan selama tiga jam tersebut. Perolehan penjualan yang diperolah, maka dibagi dua dengan pihak wali murid (orang tua). Hasil penjualan tentunya bukan dikantongi sendiri oleh siswa, melainkan dimasukkan ke dalam uang kas kelas. Sesuai dengan informasi dari kepala sekolah SDIT Al-Huda sebagai berikut:

Setelah kegiatan business day schoolselasai siswa kembali ke kelasnya masing-masing untuk mengumpulkan hasil uang tadi dan akan menghitung barang yang masuk, barang yang keluar, barang yang laku, barang yang tidak laku, dari wali murid harganya berapa, setelah itu kelas ngambil untung berapa, mau dijual berapa, setelah itu uang disisikan, ini yang keuntungannya atau labanya, ini yang kembali kepada wali murid. Setelah itu labanya disimpan ke kas kelas masingmasing sehingga ketika ada kegiatan apapun di kelas peserta didik sudah tidak memakai uang jajannya untuk di sumbangkan ke kelas kerena sudah ada uang kas hasil dari kegiatan business day school.$^{15}$

Peran guru dalam penerapan business day schooladalah sebagai pendamping yang bertugas mendampingi dan memberi arahan kepada siswatentang kegiatan ekonomi yang sesungguhnya, seperti yang disampaikan oleh Waka Kesiswaan SDIT Al-Huda sebagai berikut:

Peran sebagai guru yakni mendidik anak bukan hanya pintar dalam kemampuan Akademik namun juga hal yang lainnya. Di dalam

\footnotetext{
${ }^{14}$ Evi Cornelia Sinsu, Waka kurikulum SDIT Al-Huda, wawancara, Bawean 23 April 2019.

${ }^{15}$ Elia Puspa, Kepala sekolah SDIT Al-Huda, wawancara, Bawean, 5 April 2019.
} 
business day guru mengajarkan kepada anak cara berbisnis yakni cara mengelola keuangan, cara bertransaksi yang baik dan hal lainnya. ${ }^{16}$

Adapun harapan besar yang cita-citakan oleh Kepala Sekolah SDIT Al-Huda dalam kegiatan business day schooladalah agar siswanya yang lulus SD, SMP, SMA, Kuliah mempunyai keteampilan dan keberanian untuk membuka lapangan pekejaan sendiri agar tidak sampai menjadi pengangguran, seperti penuturan beliau sebagai beikut :

Saya tidak ingin anak-anak lulus SD, SMP, SMA dan kuliah nganggur, artinya mereka tidak mempunyai bekal. Contoh : semua orang yang kuliah tidak semua menjadi guru itu yang jurusan pendidikan dan lain sebagainya, tidak mungkin semua orang mempunyai pekerjaan, tapi kalau orang tersebut memiliki dasar dari awal paling tidak mempunyai ilmunya. Seperti, saya tidak bakat belajar, saya bakat bisnis, dia sudah punya ilmunya karena sudah pengalaman dari kecil, dulu saya yang sekolah di SDIT Al-Huda pernah di ajari business day. ${ }^{17}$

Untuk menjaga dan pengembangan kegiatan business day school dilakukan bebeapa upaya agar kegiatan business day school ini tetap bisa berinovasi, menarik, dan meyenangkan bagi siswa Kepala Sekolah di SDIT AlHuda senantiasa mengevaluasi aktifitas yang ada di sekolah ini dengan cara mengadakan rapat di setiap hari sabtu. Dalam momen ini juga kepala sekolah beserta dewan guru mempertimbangkan kelanjutan dan cara terbaik dalam meningkatkan kualitas program business day school. Sesuai dengan informasi dari kepala sekolah SDIT Al-Huda sebagai berikut:

Setiap hari sabtu SDIT Al-Huda selalu mengadakan rapat, jadi semua dewan guru yang ada di SDIT Al-Huda harus hadir untuk melaksanakan rapat evaluasi. Rapat mengevaluasi tentang apa yang terjadi dalam satu minggu ini dan akan merancang di minggu yang akan datang, termasuk dalam evaluasi business day school. ${ }^{18}$

Sedangkan factor pendukung kemajuan program business day school dibutuhkan pemimpin yang visioner untuk megembangkannya. Dalam prosesnya dibutuhkan sebuah terobosan-terobosan untuk mengembangkan program business day school dan keputusan yang tepat. Business day schoolmerupakan salah satu program unggulan di

\footnotetext{
${ }^{16}$ Saifullah, Waka kesiswaan, wawancara, Bawean, 23 April 2019

${ }^{17}$ Elia Puspa, Kepala sekolah SDIT Al-Huda, wawancara, Bawean, 5 April 2019.

${ }^{18}$ Elia Puspa, Kepala sekolah SDIT Al-Huda, wawancara, Bawean, 5 April 2019.
}

Dirasah, Vol. 3, No.2, Agustus 2020 
SDIT Al-Huda, sehingga peran dan dukungan dari kepala sekolah dibutuhkan secara penuh dalam kegiatan business day school. Sesuai dengan informasi kepala sekolah SDIT A-Huda sebagai berikut "Sekolah atau yayasan sangat mendukung dengan adanya kegiatan manajemen business day ini karena mempunyai manfaat yang sangat luar biasa bagi siswa". ${ }^{19}$

Dalam perkembangan pelaksanaan program business day school pun juga memiliki beberapa kendala yang dihadapi, seperti yang di informasikan oleh kepala sekolah SDIT A-Huda sebagai berikut:

Hambatan dalam kegiatan business day schooldi SDIT Al-Huda yaitu tidak memiliki tempat yang permanen, saya sebagai kepala sekolah berkeinginan mempunyai terop sendiri, biar kedepannya ketika hujan anak-anak dan guru sudah tidak sibuk lagi mengangkat standnya masuk. $^{20}$

\section{Hasil Penelitian}

Penerapan kegiatan business day schoolmerupakan salah satu strategi pendidikan karakter yang dilakaukan oleh SDIT Al-Huda Sangkapura yang bertujuan untuk memberikan pemahaman yang lebih mudah dan sederhana tentang kewirausahaan, dimana didalamnya akan terbentuk sebuah struktur emosi dan mentalistas siswa yang lebih stabil, mampu membangun sikap siswa yang lebih mandiri, komunikatif dan percaya diri dalam kehidupan sehari-hari. Business day schoolmerupakan program unggulan pembelajaran enterpreneur, dimana siswa di SDIT Al-Huda diajarkan bagaimana proses kegiatan ekonomi yang sesungguhnya.

Sesuai dengan tujuan utama diadakannya kegiatan business day school di SDIT Al-Huda yaitu untuk menumbuhkan jiwa kewirausahaan atau enterpreneurship. Pendidikan kewirausahaan menjadi penting diajarkan kepada siswa sebagai bekal ketrampilan dimasa depan siswa, selain itu sebagai penanaman nilai kewirausahaan. Karena sekolah adalah organisasi pendidikan yang mempunyai perananpenting dalam mencetak generasi muda yang berkarakter.

Meskipun sekolah memiliki peranan penting dalam pelaksanaanpendidikan kewirausahaan, namun tanpa ada dukungan dari pihak

\footnotetext{
${ }^{19}$ Elia Puspa, Kepala sekolah SDIT Al-Huda, wawancara, Bawean, 5 April 2019.

${ }^{20}$ Elia Puspa, Kepala sekolah SDIT Al-Huda, wawancara, Bawean, 5 April 2019
} 
lain punsemua akan sulit untuk dijalankan. Perlu adanya kerja sama yang baik antarapihak sekolah, keluarga, dan masyarakat agar pendidikan kewirausahaandapat dijalankan dengan baik.Hal ini sejalan dengan pendapat Guruvalah dalam Mulyani yang mengatakan bahwa "pendidikan kewirausahaan, dilihat dari siapa yang bertanggung jawab". Kebehasilan program business day school di SDIT Al-Huda merupakan hasil dari kerjasama dan dukungan semua pihak, baik dari pengelola lembaga pendidikan, masyarakat sekitar dan keluarga dari siswa, karena sesungguhnya pendidikan kewirausahaan dalam membetuk karakte siswa ini merupakan tanggung jawab besama. Sepeti halnya kegiatan business day school di SDIT Al-Huda mendapat dukungan baik dari pihak kepala sekolah, ketua yayasan, orang tua dan masyarakat. Hal ini disebabkan karena pembelajaranbusiness day schooldi SDIT Al-Huda telah dilaksanakan dengan sangat baik dan tepat dalam penanaman nilai-nilai kewirausahaan kepada siswanya, sehingga diharapkan dimasa depan siswa dapat membuat lapangan pekerjaan sendiri dan mampu besaing dengan peubahan zaman tentunya dengan karakter warausaha yang kuat.

Nilai-nilai kewirausahaan ditanamkan kepada seluruh siswa, siswa yang awalnya belum memiliki jiwa kewirausahaan, kemandirian, hitung aritmatika cepat, percaya diri dan komunikatif akan terus di dampingi oleh guru agar jiwa-jiwa kewirausahaan itu dapat terinternalisasi dan tumbuh dalam diri siswa. Jadi, jiwa kewirausahaan dapat dipelajari dan ditumbuhkan kepada semua siswa, meskipun mereka bukan anak dari pengusaha. Hal terpenting dan utama adalah semangat untuk terusmencoba belajar dari pengalaman.Ada beberapanilai-nilai karakte kewirausahaan yang dapat dipelajari olehsiswadi SDIT Al-Huda dalam kegiatan business day school, diantaranya kemandirian, aritmatika, percaya diri dan komunikatif. Dengan kemampuan yang dimiliki oleh siswa yang tesebut diatas, siswa mempunyai keberanian lebih dalam memasarkan produknya agar dibeli dan minati oleh pembeli yaitu teman, guru, wali siswa dan masyarakat yang bekunjung.

Kegiatan business day school memiliki peran yang sangat penting dalam meningkatkan kualitas karakter siswa karena dalam penerapan kegiatan business day school siswa berinteraksi satu sama lain, mulai dari

\footnotetext{
${ }^{21}$ Endang Mulyani dkk,Pengembangan Pendidikan Kewirausahaan,(Jakarta: Badan Pelatihan dan pengembangan Pusat Kurikulum, 2010 ).
}

Dirasah, Vol. 3, No.2, Agustus 2020 
merencanakan, pembelian barang, pelaksanaan produksi, pemasaran dan pelaporan keuangan. Pada tahap perencanaan kegiatan business day schoolmembutuhkan banyak pihak yang terlibat dalam penyusunan program diantaranya pengurus yayasan, kepala sekolah, guru, siswa, komite sekolah, dan wali murid.Perumusan kebijakan diawali dengan pemaparan visi, misi, dan tujuan sekolah mengenai kegiatan business day school. Struktur organisasi kegiatan business day schooldi SDIT Al-Huda menjadi tanggung jawab kepala sekolah, namun dalam pelaksanaan bagian kurikulum dan kesiswaan memiliki peran untuk mengatur dan merencanakan program, sedangkan pada tahap pelaksanaan diserahkan kepada guru atau wali kelas.

Kegiatan business day school dapat dilakukanmelalui program-program yang diterapkan di sekolah dasar. Kegiatan manajemen business day school merupakan Program unggulan di SDIT Al-Huda. Business day school mampu membentuk siswa menjadi pribadi yang mempunyai karakte kewirausahaan yang kuat, karena bukan hanya belajar teori tentang kewirausahaan saja, namun juga mempraktekkan secara langsung, sehingga siswa dapat belajar, mulai dari perencanaan, pembelian barang, pelaksanaan produksi, pemasaran, sampai kepelaporan keuangan.

Semua siswa sangat antusias menyambut pelaksanaan business day school, dikarenakan siswa merasa ada hal yang berbeda dari hari-hari biasa dalam kegiatan belajar megajar di sekolah. Hal inilah yang seharusnya diangkat dan selalu dihadirkan dalam lingkungan sekolah. Pada saat pelaksanaannya siswa yang bertugas dengan penuh tanggung jawab merencanakan stand untuk berjualan, mempersiapkan barang-barang yang akan di jual dan lain sebagainya. Sedangkan wali kelas bertugas sebagai pendamping. Secara bergiliran sesuai dengan kelompok yang sudah dibagi oleh wali kelas siswa yang bertugas memproduksi dan menjual barang. Siswa yang lain beserta orang tua murid dan masyarakat berperan sebagai pembeli pada kegiatan business day school.

Dibutuhkan peran kepala sekolah yang efektif dalam setiap pengambilan keputusan yang tidak mudah, tidak hanya sekedar cerdas dan berpendidikan tinggi saja melainkan harus memiliki sebuah mentalitas dari seorang pemimpin efektif. Hal ini senada dengan pendapat Alben Ambarita bahwa "seorang kepala sekolah yang efektif memiliki sikap-sikap yang efektif yakni: Visioner, meyakini sekolah sebagai wahana belajar, berorientasi kepada 
kepuasan kerja, menghargai SDM, pro-aktif, berkomunikasi efektif dan berani mengambil resiko". 22

Kepala sekolah merupaka tenaga fungsional yang diberikan wewenang dan kepercayaan dari lembaga pendidikan tertentu untuk merencanakan, mengatur, mengontrol, dan mengevaluasi segala kebijakan-kebijakan yang ada di lembaga pendidikan tersebut demi tercapainya visi dan misi pendidikan nasional. Hal ini senada dengan pendapat Wahjosumidjo dalam Euis Karwati yang mengatakan bahwa secar profesional kepala sekolah memiliki tugas-tugas diantaranya (1) Kepala sekolah berperilaku sebagai saluran komunikasi di lingkungan sekolah yang di pimpinnya, (2) Kepala sekolah bertindak dan bertanggung jawab atas segala tindakan yang dilakukan oleh guru, staf, dan pegawai lainnya yang ada di sekolah, (3) Dengan waktu dan sumber yang terbatas, kepala sekolah harus mampu menghadapi berbagai persoalan, (4) Kepala sekolah harus berfikir secara analitik dan konsepsional, (5) Kepala sekolah adalah seorang mediator atau juru penengah, (6) Kepala sekolah adalah seorang politisi, (7) Kepala sekolah adalah seorang diplomat, (8) Kepala sekolah harus mampu mengambil keputusan-keputusan sulit.

Dalam kegiatan business day schoolkepala sekolah senantiasa mengevaluasi aktifitas yang ada di SDIT Al-Huda dengan cara mengadakan rapat di setiap akhir pekan. Dalam momen ini juga kepala sekolah beserta dewan guru mempertimbangkan kelanjutan dan cara terbaik dalam meningkatkan kualitas program business day school.Ada beberapa tugas-tugas profesional yang sudah di lakukan oleh kepala sekolah SDIT Al-Huda di antaranya melakukan evaluasi secara rutin yakni evaluasi yang dilakukan di SDIT Al-Huda. Kemudian pengambilan keputusan-keputusan secara bijak, sehingga dengan pengambilan keputusan dengan menjadikanbusiness day school menjadi program unggulan di SDIT Al-Huda.

\section{Penutup}

Peran kepala sekolah SDIT Al-Huda dalam kegiatan business day schoolsenantiasa mengevaluasi aktifitas yang ada di SDIT Al-Huda dengan cara mengadakan rapat secara rutin di akhir pecan dengan merencanakan, mengatur, mengontrol, dan mengevaluasi segala kebijakan-kebijakan yang ada di lembaga pendidikan tersebut demi tercapainya visi. Dalam momen ini juga

\footnotetext{
${ }^{22}$ Alben Ambarita,kepemimpinan kepala sekolah,(Yogyakarta: Graha ilmu, 2015), 89-91.
}

Dirasah, Vol. 3, No.2, Agustus 2020 
kepala sekolah beserta dewan guru mempertimbangkan kelanjutan dan cara terbaik dalam meningkatkan kualitas program Kegiatan business day schoolmemiliki peran yang sangat penting dalam meningkatkan karakter siswa karena dalam penerapan kegiatan business day school siswa berinteraksi satu sama lain, mulai dari merencanakan, pembelian barang, pelaksanaan produksi, pemasaran dan pelaporan keuangan. Kegiatan business day schoolmemiliki peran yang sangat penting dalam meningkatkan karakter siswa karena dalam penerapan kegiatan business day school siswa berinteraksi satu sama lain, mulai dari merencanakan, pembelian barang, pelaksanaan produksi, pemasaran dan pelaporan keuangan. Kegiatan business day schoolmerupakan Program unggulan di SDIT Al-Huda.

\section{Daftar Pustaka}

Alben ambarita,kepemimpinan kepala sekolah, Yogyakarta : Graha ilmu, 2015

Daniel Geloman, penerjemah: T. Hermaya, kecerdasan Emosional,(Jakarta : PT. Gramedia Pustaka Utama, 2009).

Ela fitria rahma, "Menumbuhkan Kemampuan Enterpreneurship Anak Melalui Kegiatan Market Day di Kelompok B TK putri Serang Sumber Surakarta" (Skripsi Universitas Muhammadiyah, Surakarta, 2016).

Endang Mulyani dkk,Pengembangan Pendidikan Kewirausahaan,(Jakarta: Badan Pelatihan dan pengembangan Pusat Kurikulum), 2010.

Euis karwati,kinerja dan profesionalisme kepala sekolah,(Bandung : Alfabeta, 2013).

Muhaimin, dkk., "Manajemen Pendidikan: Aplikasi dalam Peyusunan Rencana Pengembangan Sekolah /Madrasah", Kencana. Jakarta, 2011

Wulan Ayodya,Siswa Juga Bisa Jadi Pengusaha: Tips dan Trik Belajar Berwirausaha Bagi Siswa,(Jakarta : Esensi, 2011)

Elia Puspa, Kepala sekolah SDIT Al-Huda.wawancara, Bawean 23 April 2019 Evi Cornelia Sinsu, Waka kurikulum SDIT Al-Huda, wawancara, Bawean 23 April 2019.

Saifullah, Waka kesiswaan, wawancara, Bawean, 23 April 2019 
Copyright (C) 2020Journal Dirasah: Vol. 3, No.2, Agustus 2020, p-ISSN: 2615-0212, e-ISSN; 2621-2838

Copyright rests with the authors

Copyright of Jurnal Dirasah is the property of Jurnal Dirasah and its content may not be copied oremailed to multiple sites or posted to a listserv without the copyright holder's express writtenpermission. However, users may print, download, or email articles for individual use. https://ejournal.iaifa.ac.id/index.php/dirasah 